2004; 89: 890-891. doi:10.1136/adc.2003.045070.

4. Lamah M, McCaughey ES, Finlay FO, Burge DM. The ascending testis: is late orchidopexy due to failure of screening or late ascent? Pediatr Surg Int 2001; 17: 421-423. doi:10.1007/s003830000535

5. Guven A, Kogan BA. Undescended testis in older boys: further evidence that ascending testes are common. $J$ Paediatr Surg 2008; 43: 1700-1704.

6. Stec AA, Thomas JC, De Marko RT, et al. Incidence of testicular ascent in boys with retractile testes. J Urolog 2007; 178: 1722-1725.

7. Agarwal PK, Diaz M, Elder JS. Retractile testis - is it really a normal variant? J Urology 2006; 175: 1496-1499.

8. Royal College of General Practitioners. RCGP Child Health Strategy 2010-2015. London: Royal College of General Practitioners, 2010.
http://www.rcgp.org.uk/pdf/CIRC_RCGP_Child_Health Strategy_2010_2015_FINAL.pdf (accessed 9 Feb 2011).

9. Royal College of Nursing. Getting it right for teenagers in your practice. 2007.

http://www.rcn.org.uk/_data/assets/pdf_file/0008/78542 001798.pdf. (accessed 28 Jan 2011).

10. Royal College of General Practitioners. Safeguarding children and young people: a toolkit for general practice 2009 revision.

http://www.rcgp.org.uk/docs/CIRC_Toolkit\%202009\%20 final (accessed 28 Jan 2011)

11. UK, Department of Health. National service framework for children, young people and maternity services: executive summary. London: Department of Health, 2004.

http://www.dh.gov.uk/en/Publicationsandstatistics/Public ations/PublicationsPolicyAndGuidance/DH_4089100 (accessed 28 Jan 2011).
DOI: 10.3399/bjgp11X561104

ADDRESS FOR CORRESPONDENCE

Nigel Mathers

Academic Unit of Primary Medical Care, University of Sheffield, Samuel Fox House, Northern General Hospital, Herries Road, Sheffield, S5 7AU.

E-mail: n.mathers@sheffield.ac.uk

\title{
Revalidation:
}

\section{a critical perspective}

As the stadium for the 2012 Olympics rises brick by shining brick against the London skyline, the apparatus for revalidation of doctors in the UK is currently being constructed to a similar timetable (although tellingly, no date has been set for its opening ceremony). ${ }^{1}$ Revalidation's goals appear to be threefold: restore public trust in the medical profession; support professional development in all doctors; and weed out the bad apples..$^{2-4}$ Many have pointed out that these goals may conflict (for example, professional development is a formative and supportive process, while dealing with unacceptably poor practice must surely be summative and judgemental) and that the evidence base linking the proposed input (5yearly assessment of a portfolio) with the desired outcome (better, safer care for patients) is all but absent. ${ }^{5-8}$

\section{SPARSE EVIDENCE BASE}

The research literature on revalidation is indeed sparse. For example, a single randomised trial in 66 Scottish GPs compared a light-touch, 'criterion-based' model with a more comprehensive, 'educational outcome' model; there were no differences in what was recorded in the portfolios or in self-reported changes in practice, but participants preferred the former model. ${ }^{9}$ In this study of volunteers, $20 \%$ of doctors did not hand in their portfolio and impact on patient care was not measured. Professional certification status in the US has been depicted as having led to improvements in quality of care, but online responses pointed out that association in an uncontrolled study does not prove causation. ${ }^{10}$

We could find only one paper which applied an explicit theoretical model of professional practice to revalidation: 6 years ago, Paul Thomas argued in this Journal that:

'Shipman could have passed tests for medical competence. It was someone unafraid to ask 'why do so many of your patients die?' that found him out ... Revalidation must lead to an environment where supportive asking of uncomfortable questions becomes the norm."

Thomas considered this crucial questionasking at three levels: individual (Schon's 'reflective practitioner'), organisational (Senge's 'learning organisation') and system (Lave and Wenger's 'community of practice'). He concluded that individual revalidation, however well implemented, was only one component of a process which should also include organisational and system assessments.

\section{AN UNEASY PROFESSION}

In The Doctor's Dilemma, George Bernard
Shaw reminded us that 'All professions are a conspiracy against the laity'. Perhaps in acknowledgement of their undeniable conflict of interest, doctors' official opposition to revalidation has been muted. But anecdotally, and in the relative safety of the online blog or letter to the 'GP freebies', doctors are predicting that revalidation will be an inefficient, deprofessionalising, and overly bureaucratic process which for those approaching retirement age will not be worth the candle. Once it becomes compulsory, they say, they will not carry on.

Tim van Zwanenberg perceptively questioned whether revalidation would be sufficiently 'sensitive (identify poor performance), specific (identify educational needs), valid (reflect actual clinical practice), or reliable (behave consistently across cohorts of doctors)'.2 Important though these attributes of revalidation as a process are, there are some even more fundamental, extra-individual questions about revalidation as a policy. Where did it come from? What is its ideological basis? Whose interests will it serve? What power shifts are implicated in its introduction? What language is used in the policy and what does this symbolise? How, for example, is 'good professional practice' defined and framed? What is not talked about and why?

\section{A POLICY 'OF ITS TIME'}

Kingdon proposed that the policymaking 
arena can be thought of as a 'primeval soup' of ideas and possibilities from which fully-formed policies may emerge if and when particular alignments of interests and priorities come together. ${ }^{11}$ Revalidation as an idea has been around for years, but the origins of the current proposals can be traced back to Dame Janet Smith's Shipman Inquiry, which warned that the cosy measures originally put forward by the General Medical Council (GMC) were inadequate to protect the public from the perils of unscrupulous doctors. ${ }^{12}$ Revalidation, she suggested, was not fit for purpose, and its responsibility needed to be taken away from the GMC and handed over to the clinical governance structures of a primary care organisation. Better 'evidence' was needed of doctors' fitness to practice, as was the involvement of lay people.

\section{A COMPLEX PROVENANCE}

The part-finished assemblage of standards, documentation, systems, and procedures that will go live from 2012 has been put together by government, the GMC (referred to as 'the regulator'), the Department of Health, the British Medical Association (BMA), the Academy of Medical Sciences, the Royal Colleges, and the National Institute for Health and Clinical Excellence with input from (or at least, formal consultation with) representatives of patients and the public. This list of venerable institutions should not be viewed as implying universal support from their members, as Glyn Elwyn's account of dissent in the ranks of the Royal College of General Practitioners (RCGP) illustrates. ${ }^{\circ}$

\section{TOOLKIT PROFESSIONALISM}

The essential component for revalidation will be a review of a file of documents (Box 1). These will be compared against standards and expectations, both for formative assessment and as a screening mechanism to identify possiblyunderperforming individuals who will be required to undergo further checks. The underlying process is thus a technical and bureaucratic one. Various 'tools' have been produced to help achieve it (see, for example, https://gpeportfolio.rcgp.org.uk and https://www.revalidationplus.co.uk). The robustness of this model is (allegedly) assured through its rigorous, standardised and comprehensive methodology.

Rationalism has strong rhetorical appeal, especially when lives are at stake. Anything less than a thorough and systematic checkup on every doctor every few years, to agreed 'evidence-based' standards, seems half-hearted and unprofessional. But doctors are right to feel uneasy. As Simon Cohn argued recently in relation to 'rational' arguments for banning flowers from hospital wards:

'The development is not the
articulation of rational science but
increased rationalisation in the
sociological sense, which equates with
technical efficiency coupled with
greater bureaucracy and
accountability. The practice of
healthcare delivery - with more
prescriptive guidelines and targets,
greater demands on time, and more
explicit professional roles - means
that there is simply not room for the
more vague, apparently superfluous,
practices on a well functioning ward.
The flowers have been elbowed out.' ${ }^{13}$

Rationalism's colonisation of medical practice does not stop with the flowers. Notwithstanding attempts by the BMA and Royal Colleges to introduce 'holistic' principles, the proposed revalidation procedures elbow out a number of aspects of professional practice that many doctors (and, importantly, patients) hold dear. Revalidation policy aligns with an ideological position, which Steve Harrison has dubbed 'scientific-bureaucratic medicine', characterised by three things: decisionmaking based on rules about what ought to be done in particular circumstances (hence 'best practice' is defined increasingly in terms of following 'if ... then' algorithms); a rise in managerialism over professionalism; and trust redefined in terms of reliability of systems and procedures instead of the virtues of the doctor. ${ }^{14}$

\section{PRAXIS DOWNGRADED?}

What does a 'rational' (technical, managerial) assessment of fitness to practice omit that a more professionally-oriented one would include? Aristotle distinguished three essential forms of knowledge: theoretical (epistēmē), technical (technē) and practical (praxis), ${ }^{15}$ to which Kemmis and Smith, drawing on the work of educationalists like Paulo Freire, added a fourth: criticalemancipatory. ${ }^{16}$

The doctor who runs a well baby clinic, for example, must be up-to-date in the evidence base on which immunisations should be offered to which children (theoretical knowledge); competent in administering the immunisations (technical or craft knowledge); able to make judgements about whether this infant with this cluster of mild, non-specific symptoms should be immunised on the same day or asked to return the following week (practice knowledge); and alert and proactive about the social determinants which explain why parents from certain socioeconomic and cultural groups are less likely to bring their infants to the clinic (critical-emancipatory knowledge).

Revalidation's strong focus on documentary evidence appears to privilege the consumption of abstracted facts on formal courses (continuing professional development [CPD] credits) over the more

\section{Box 1. Examples of documentation required in revalidation portfolio. ${ }^{1}$}

- Statement of professional roles and other basic details

- Statement of exceptional circumstances

- Evidence of active and effective participation in annual appraisals

- A personal development plan from each annual appraisal

- A review of the personal development plan from each annual appraisal

- Learning credits in each year of the revalidation period and in the revalidation period overall

- Multi-source feedback from colleagues

- Feedback from patients

Description of any cause for concern and/or formal complaint

- Significant event audits

- Clinical audits

Statement on probity and health

- Additional evidence for areas of extended practice 
diffuse accumulation of, and reflection on, professional experience. While we acknowledge genuine efforts to place reflection at the heart of appraisal and revalidation, much of the advice and guidance reflects a prevailing assumption that the more approved facts which are consumed and actioned, the better the doctor's practice will become. As a recent guidance document from the RCGP put it:

'In essence 1 hour of education is 1 learning credit. However, if that education leads to changes for patients, the doctor or the practice, the GP can claim 2 learning credits for each hour of such education ... The system will help GPs meet their revalidation needs by providing a mechanism for collecting and demonstrating their CPD credits. ${ }^{17}$

The learner in the above quote comes dangerously close to being an empty bucket into which facts are placed which produce changed behaviour and therefore patient outcomes. But all the CPD credits in the world will not equip the learner with the practical common sense which Aristotle called phronēsis. In medicine, and especially in general practice, it is not rule-based decisions that are needed most of the time so much as contextualised judgements. ${ }^{18}$ Praxis is at the heart of professional training and CPD. It is:

\begin{abstract}
'... to be a professional, a practitioner who acts morally in the interests of each client and in the interests of the good for humankind, wisely and prudently in relation to unique needs and circumstances in particular places and times, and in a way that demonstrates virtue in the form of a commitment to the goods that are internal to the practice itself. ${ }^{16}$
\end{abstract}

The 'good doctor' in this context is not someone who collects CPD points and meets performance targets (Shipman did this, remember), but a knowledgeable interpreter of situations: someone who takes wise decisions by reflecting on the here-and-now in relation to a socially shared, historically unfolding, and continually revisited understanding of what, in general, good doctoring is. Through practice, the good doctor draws on his or her virtues and embodies, reproduces, and reinforces the traditions and values of the profession. ${ }^{19}$

Perhaps praxis will be adequately captured in such things as 'multi-source feedback from colleagues' or 'significant event audits', or 'self-reflective templates' - but perhaps it won't. If medicine is considered as a social practice, we believe that far more attention needs to be paid to how individual doctors' understandings, values, and capacity to make judgements are collectively and discursively shaped through communication (verbal and written, formal and informal) within the profession. ${ }^{20}$ Kemmis and Grootenboer have coined the term 'practice architectures' to describe the shared conceptual frameworks and ways of seeing within a profession, which:

'.. prefigure practices, enabling and constraining particular kinds of sayings, doings and relatings among people within them, and in relation to others outside them. The way these practice architectures are constructed shapes practice ... giving substance and form to what is and can be actually said and done, by, with and for whom. ${ }^{21}$

\section{A RESEARCH IMPERATIVE}

As the engineers of the revalidation machinery continue their mission to replace the language of professionalism with the language of managerialism, there is a danger that 'fitness to practice' will come to mean something subtly different, and the praxis elements of good doctoring will slip farther from the regulatory gaze. ${ }^{20,21}$ If we cannot stop this happening, we should at least be entering a dialogue on how we might study the unanticipated harms of this well-intentioned policy.

\section{Trisha Greenhalgh,}

Professor of Primary Health Care and Director, Healthcare Innovation and Policy Unit Centre for Health Sciences, Barts and The London School of Medicine and Dentistry, London.

\section{Geoff Wong,}

GP Appraiser, Camden PCT and NIHR Clinical Lecturer, Division of Population Health and Primary Care, University College London, London.

\section{Provenance}

Commissioned, not externally peer reviewed.

\section{REFERENCES}

1. Royal College of General Practitioners. RCGP Guide to the Revalidation of General Practitioners. London: RCGP, 2010.

http://www.rcgp.org.uk/PDF/Guide_to_Revalidation $\% 20$ for\%20GPs_fifth_FINAL.pdf (accessed 28 Jan 2011).

2. Van Zwanenberg T. Revalidation: the purpose needs to be clear. BMJ 2004; 328(7441): 684-686.

3. Pringle M. Regulation and revalidation of doctors. BMJ 2006; 333(7560): 161-162.

4. Southgate L, Pringle M. Revalidation in the United Kingdom: general principles based on experience in general practice. BMJ 1999; 319(7218): 1180-1183.

5. Wakeford R. GMC's proposals for revalidation would not be accurate, economical, or fair. BMJ 2000; 321: 1220.

6. Elwyn G. Revalidation: cracks at first, now chasms. $\mathrm{Br} J$ Gen Pract 2005; 55(516): 562.

7. Thomas P. Will GP revalidation make things better or worse? Br J Gen Pract 2005; 55(513): 318-319.

8. Wong G. Revalidation: swallow hard. BMJ 2004; 328(7447): 1077.

9. Bruce D, Phillips K, Reid R, et al. Revalidation for general practitioners: randomised comparison of two revalidation models. BMJ 2004; 328(7441): 687-691.

10. Sutherland K, Leatherman S. Does certification improve medical standards? BMJ 2006; 333: 439-441.

11. Kingdon JW. Agendas, alternatives and public policy. New York, NY: Harper Collins; 1995.

12. Smith J. The Shipman Inquiry. Safeguarding patients: lessons from the past, proposals for the future. London: Stationery Office, 2004. http://www.the-shipmaninquiry.org.uk $/ 5 r \_p a g e . a s p ? c h=26 \& p a=191 \# 26.188$ (accessed 28 Jan 2011).

13. Cohn $\mathrm{S}$. Where have all the hospital flowers gone? BMJ 2009; 339: b5406.

14. Harrison S. New Labour, Modernisation and the medical labour process. J Soc Policy 2002; 31(3): 465-485.

15. Aristotle. Nichomean ethics. London: Penguin; 1996.

16. Kemmis S, Smith T. Personal praxis: learning through experience. In: Kemmis S, Smith T, eds. Enabling praxis: challenges for education. Rotterdam: Sense; 2008: 15-36.

17. Royal College of General Practitioners. RCGP guide to the credit-based system for CPD. London: RCGP, 2010.

18. Hunter KM. 'Don't think zebras': uncertainty, interpretation, and the place of paradox in clinical education. Theoretical Medicine 1996; 17: 225-241.

19. Toon P. Towards a philosophy of general practice: A study of the virtuous practitioner. Occas Pap R Coll Gen Pract 1999; (78): iii-vii, 1-69.

20. Schatzki TR. Introduction: practice theory. In: Schatzki TR, Knorr Cetina K, von Savigny E, eds. The practice turn in contemporary theory. London: Routledge; 2001: 1-14.

21. Kemmis S, Grootenboer P. Situating praxis in practice: practice architectures and the cultural, social and material conditions for practice. In: Kemmiss S, Smith T, eds. Enabling praxis: challenges for education. Rotterdam: Sense; 2008: 37-64.

DOI: 10.3399/bjgp11X561113

\section{ADDRESS FOR CORRESPONDENCE}

Trisha Greenhalgh,

Healthcare Innovation and Policy Unit, Centre for Health Sciences, Barts and The London School of Medicine and Dentistry, Abernethy Building, 2 Newark Street, London E1 2AT.

E-mail:p.greenhalgh@qmul.ac.uk 